\title{
ANALISIS FISHING ACTIVITY KAPAL TUNA LONGLINE MENGGUNAKAN VESSEL MONITORING SYSTEM YANG BERBASIS DI BENOA BALI
}

\section{ANALYSIS FISHING ACTIVITY TUNA LONGLINE USING VESSEL MONITORING SYSTEM BASE ON BENOA BALI}

\author{
Muhammad Irsyad Tawaqal ${ }^{1}$, Roza Yusfiandayani ${ }^{2}$, Mohammad Imron ${ }^{2}$ \\ ${ }^{1}$ Program Studi Teknologi Perikanan Laut, Sekolah Pascasarjana \\ ${ }^{2}$ Departemen Pemanfaatan Sumberdaya Perikanan, \\ Fakultas Perikanan dan Ilmu Kelautan, Institut Pertanian Bogor \\ Korespondensi: muhammad_irsyad93@apps.ipb.ac.id
}

\begin{abstract}
Tuna fisheries based on Benoa fishing port has undergone major changes since 1993 when yellowfin tuna dominated the catch, followed by big eye tuna and other types of tuna. Fishing vessels to catch tuna in Benoa, Bali, are dominated by tuna longline, purse seine, and troll line vessels. Vessels that are up to 30 GT (>30 GT) must install the Vessels Monitoring System (VMS) to surveillance the fishing vessels that are operating following by the regulations. VMS data provide lot of data from vessel movment, but the problem is not used optimally and the analysis of data VMS still in development, therefore this research aims to identify the utilization VMS data for survilliance dan management of tuna longline based at Benoa. The method used was descriptive analysis using a spatial data management application. The results showed that VMS data can be used to know fishing activity such as vessel position, vessel velocity, and vessel movement. Fishing activity with VMS data can indentfy infraction did by tuna longline vessel that indicated transshipment activity, infraction of fishing area, and can used to validate data between logbook data and VMS data when the vessel landed a fish catch at port. Cross matching data between VMS and logbook data show that data suitability from 2016-2018 increase in 2016 suitability data get 53\%, then 2017 get $94 \%$, and 2018 get $98 \%$.
\end{abstract}

Keywords: logbook, vessel behavior, vessel tracking

\begin{abstract}
ABSTRAK
Perikanan tuna yang berbasis di Pelabuhan Benoa telah mengalami perubahan besar sejak tahun 1993 ketika ikan sirip kuning mendominasi hasil tangkapan diikuti tuna mata besar dan tuna jenis lainnya. Kapal yang beroperasi yang berbasis di Benoa Bali untuk menangkap ikan tuna didominasi oleh kapal tuna longline, purse seine, dan pancing tonda, untuk mengawasi kapal yang beroperasi agar sesuai dengan peraturan maka kapal yang beroperasi (>30 GT) diwajibkan memasang Vessel Monitoring System (VMS). Data VMS menyediakan banyak data dalam jumlah besar dari gerakan kapal perikanan, namun permasalahannya adalah belum digunakan secara maksimal dan analisis data tersebut masih dalam perkembangannya, oleh karena itu penelitian ini bertujuan untuk mengidentifikasi pemanfaatan data olahan VMS untuk pengawasan dan pengelolaan perikanan tuna longline yang berbasis di Benoa. Metode yang digunakan adalah adalah analisis deskriptif dengan menggunakan aplikasi pengelola data spasial. Hasil penelitian menunjukkan bahwa data VMS dapat dimanfaatkan untuk mengetahui aktivitas penangkapan seperti posisi kapal, kecepatan kapal, dan arah gerak kapal. Aktivitas penangkapan dengan data VMS dapat mengidentifikasi adanya pelanggaran yang dilakukan oleh kapal tuna longline seperti kapal yang diindikasikan melakukan kegiatan transshipment, pelanggaran daerah penangkapan ikan dan ketidaksesuaian data logbook dan data VMS ketika kapal melakukan pendaratan hasil tangkapan ikan. Crossmatching data VMS dan data logbook menujukkan bahwa kesesuaian data dari tahun 2016-2018 mengalami peningkatan yakni tahun 2016 kesesuaian data mencapai 53\%, kemudian tahun 2017 sebesar 94\%, dan 2018 sebesar 98\%.
\end{abstract}

Kata kunci: logbook, vessel behavior, vessel tracking 


\section{PENDAHULUAN}

Menurut Jatmiko (2016) secara umum, estimasi produksi madidihang yang didaratkan di Benoa menurun drastis sekitar 50\% dari 5.300 ton di tahun 2010 menjadi hanya sekitar 2.600 ton di tahun 2014. Estimasi produksi tuna mata besar cenderung stagnan dari tahun ke tahun dengan estimasi produksi berkisar antara 2.000-2.500 ton setiap tahunnya. Sedangkan estimasi produksi tuna sirip biru selatan mengalami peningkatan yang cukup signifikan dari 180 ton di tahun 2010 menjadi 950 ton di tahun 2014. Terjadinya fluktuasi produktivitas tuna di Benoa diperkirakan disebabkan oleh kegiatan IUU fishing salah satunya adalah kegiatan transhipment. Kegiatan alih muat merupakan kegiatan yang cukup strategis dalam pelaksanaan usaha perikanan pada kapal tuna longline namun dengan dikeluarkannya Peraturan Menteri Kelautan dan Perikanan Republik Indonesia nomor 57/Permen-KP/2014 tentang Perubahan Kedua atas Peraturan Menteri Kelautan dan Perikanan Nomor PER.30/MEN/2012 tentang Usaha Perikanan Tangkap di Wilayah Pengelolaan Perikanan Negara Republik Indonesia sebagai dasar pelarangan pindah muatan di laut (transhipment). Hal di atas menjadi masalah bagi pelaku usaha perikanan dan juga pemerintah. Kegiatan transhipment memberikan keuntungan untuk kapal perikanan karena dapat memindahkan hasil penangkapannya ke kapal lain di tengah laut dan dapat melanjutkan operasi penangkapannya tanpa harus kembali ke pelabuhan, hal ini dapat menghemat biaya bahan bakar dan distribusi produk ke pasar lebih cepat. Hal ini jelas memberikan keuntungan finansial untuk para pelaku usaha perikanan. Namun disisi lain Indonesia sebagai salah satu anggota Port State Measures memiliki kewajiban untuk mengatasi IUU Fishing di wilayah sekitarnya, memberikan data hasil penangkapan yang didaratkan, dan mendukung fishing activity (FAO 2007). Hal ini didukung dengan dikeluarkannya Permen Per.05/ MEN/2007 tentang penyelenggaraan sistem pemantauan kapal perikanan dan juga Permen KP Nomor 42/PERMEN-KP/2015 tentang sistem pemantauan kapal dimana pada BAB V pasal 12 butir satu disebutkan bahwa "Setiap kapal berukuran 30 GT yang beroperasi di WPNRI dan di laut lepas wajib memasang transmitter SPKP". Data VMS menyediakan banyak data dalam jumlah besar dari gerakan kapal perikanan, namun belum digunakan secara maksimal dan analisis data tersebut masih dalam perkembangan (Natsir 2013). Oleh karena itu, diduga masih banyak pengolahan data VMS yang dapat digunakan untuk kepentingan pengawasan dan pengelolaan perikanan. Bedasarkan permasalahan tersebut, maka perlu dilakukan kajian untuk merumuskan pemanfataan data VMS lainnya yang dapat digunakan untuk upaya pengawasan dan pengelolaan perikanan dan menjadi rekomendasi untuk pemerintah.

\section{METODE PENELITIAN}

\section{Waktu dan tempat penelitian}

Penelitian ini dilakukan di Pelabuhan Benoa Bali dan Kementrian Kelautan Perikanan pada bulan Agustus-September 2019.

\section{Jenis dan sumber data}

Jenis data yang digunakan dalam penelitian ini adalah data sekunder (data berkala) selama 3 tahun dari tahun 20162018 hal ini didasari berdasarkan penelitian sebelumnya dimana data produksi tuna yang digunakan produski tuna dari tahun 2010-2015 sehingga data yang digunakan untuk penelitian ini dari tahun 20162018. Data yang digunakan meliputi data produksi (logbook) tuna yang didaratkan di Pelabuhan Benoa Bali dan data VMS dari kapal longline yang berbasis di Pelabuhan Benoa. Metode yang digunakan dalam penelitian ini adalah metode probability sampling. Teknik pengambilan data dalam penelitian ini menggunakan disproportionate stratified random sampling dimana teknik pengambilan sampel yang dilakukan karena sifat atau unsur dalam populasi tidak homogen dan berstrata secara kurang atau tidak proporsional, dikarenakan kapal yang akan dijadikan sampel ukuran populasinya tidak proposional maka teknik pengambilan data menggunakan teknik disproportionate stratified random sampling dengan melakukan pembagian strata berdasarkan grosstonage kapal yakni kapal dengan ukuran 30-100 GT dan diatas 100 GT. Menurut data dari Ditjen PSDKP KKP 2018 kapal longline dengan transmitter yang aktif terdapat 178 unit beroperasi di Pelabuhan Benoa. Berdasarkan Peraturan Menteri Kelautan dan Perikanan Nomor 
42/PERMEN-KP/2015 tentang Sistem Pemantauan Kapal Perikanan disebutkan bahwa setiap kapal perikanan berukuran lebih dari 30 GT yang beroperasi di Wilayah Pengelolaan Perikanan Negara Republik Indonesia (WPPNRI) dan di laut lepas wajib memasang transmitter SPKP, oleh karena itu data yang akan dijadikan sampel adalah kapal yang memiliki ukuran 30 GT keatas. Berikut disajikan data pada Tabel 1 tentang jumlah kapal yang akan dijadikan sampel penelitian berdasarkan klasifikasi grosstonage kapal.

Berdasarkan Gay \& Diehl (1992) menyatakan bahwa untuk analisis deskriptif jumlah sampel yang diambil sebesar 10\% dari populasi yang ada. Sehingga jumlah sampel untuk kapal yang berukuran 30-60 GT adalah sebanyak 12 unit kapal longline sedangkan untuk kapal di atas 100 GT sebanyak 6 sampel.

\section{Pengumpulan data}

Pengumpulan data VMS dilakukan di Kementerian Kelautan dan Perikanan Ditjen Pengawasan Sumberdaya Kelautan dan Perikanan bagian Pengendalian Operasi Armada (POA). Data VMS yang tersedia data berupa waktu keberadaan kapal, posisi kapal, arah gerak kapal, dan kecepatan kapal. Data logbook yakni data keberangkatan kapal dan data kedatangan kapal yang didapatkan di pangkalan pengawasan Benoa Bali dari tahun 20162018 yang meliputi data tanggal kapal melakukan pendaratan hasil tangkapan, jumlah dan jenis hasil tangkapan, dan waktu kapal meninggkalkan pelabuhan untuk melakukan operasi penangkapan ikan.

\section{Analisis data}

Analisis data yang digunakan dalam penelitian ini adalah analisis deskriptif dengan menggunakan aplikasi QGIS sebagai aplikasi pengolahan data spasial. Data VMS yang diperoleh dari Pusat Pengendalian (Pusdal) PSDK KKP diunduh dengan waktu yang bisa ditentukan mulai dari harian, bulanan, tahunan, dan waktu yang bisa ditentukan sesuai dengan kebutuhan. Data VMS berupa data titik yang memiliki interval waktu 1 jam setiap titiknya (ping) dengan format CSV (Comma Separated Value). Data VMS yang diperoleh memiliki 11 atribut yang akan diolah untuk mengetahui aktivitas kapal perikanan. Data atribut VMS akan disajikan dalam Tabel 2.

Tabel 1. Ukuran kapal longline berdasarkan grosstonage kapal

\begin{tabular}{cccc}
\hline No & $\begin{array}{c}\text { Ukuran Kapal } \\
\text { (GT) }\end{array}$ & $\begin{array}{c}\text { Jumlah } \\
\text { (Unit) }\end{array}$ & $\begin{array}{c}\text { Jumlah sampel yang diambil } \\
\text { (Unit) }\end{array}$ \\
\hline 1 & $30-100$ & 123 & 12 \\
2 & $>100$ & 55 & 6 \\
\hline
\end{tabular}

Sumber: Ditjen PSDKP tahun 2018

Tabel 2. Data atribut VMS

\begin{tabular}{cll}
\hline No. & \multicolumn{1}{c}{ Atribut } & \multicolumn{1}{c}{ Keterangan } \\
\hline 1 & tanggal & Data berupa tanggal dan waktu titik kapal berada \\
2 & id_traffic & Data unik untuk setiap titik posisi kapal \\
3 & transmitter & Nomer identifikasi kapal yang menggunakan VMS \\
4 & Lon & Longitude \\
5 & Lat & Latittude \\
6 & Nama kapal & Nama Kapal \\
7 & Spd & Kecepatan kapal di setiap titik \\
8 & heading & Arah gerak kapal di setiap titik \\
9 & ukuran_gt & Ukuran grostonase kapal \\
10 & alat_tangkap & Jenis alat tangkap yang digunakan \\
11 & id_vessel & Identifikasi kapal pada dokumen \\
\hline
\end{tabular}


Kemudian data VMS yang telah diperoleh akan di akan diimport ke dalam QGIS dan dianalisis menggunakan plugins trajectory yang dapat menampilkan garis yang menghubungkan titik-titik yang diinterpretasikan sebagai posisi kapal, kecepatan kapal, dan arah gerak kapal dari data VMS. Data posisi kapal, kecepatan kapal, dan arah kapal yang akan di layoutkan dengan peta perairan Indonesia akan menghasilkan visualisasi pola dari aktivitas penangkapan kapal tuna longline dan juga dapat mengidentifikasi daerah penangkapan ikan berdasarkan tingkat aktivitas kapal tuna longline dan jumlah kapal yang melakukan operasi penangkapan ikan dalam satu area yang sama. Data kecepatan kapal digunakan untuk menentukan apakah kapal sedang melakukan setting, hauling, soak-time, dan steaming. Data posisi kapal tuna longline digunakan untuk menentukan apakah kapal tuna longline melakukan aktivitas operasi penangkapan ikan sudah sesuai dengan dokumen perizinan yang telah ditentukan. Data posisi kapal juga digunakan untuk mengidentifikasi apakah kapal tuna longline berada di pelabuhan atau tidak pada saat kapal melakukan bongkar muat, hal ini dilakukan untuk menanggulangi unreported fishing. Selain itu, data posisi kapal juga dapat mengidentifikasi kapal tuna longline yang diindikasikan melakukan pelanggaran seperti kapal yang diindikasikan melakukan transhipment dan pelanggaran daerah penangkapan ikan. Data posisi kapal juga digunakan untuk memvalidasi posisi kapal ketika kapal melakukan bongkar muat hasil penangkapan apakah kapal berada di pelabuhan atau tidak hal ini dilakukan yang dibandingkan dengan data logbook untuk menanggulangi unreported fishing yang dapat menyebabkan ketidakakuratan data. Data arah gerak kapal digunakan untuk menentukan arah gerak kapal tuna longline ke arah daerah penangkapan ikan, ke arah pelabuhan atau kemana arah kapal berlayar sehingga dapat diketahui pada bulan apa kapal melakukan keberangkatan. Memperoleh data distribusi spasio-temporal yang baik dari fishing activity dan effort yang dilakukan oleh kapal penangkapan ikan memerlukan analisis dari aktivitas kapal di tengah laut karena data logbook tidak dirancang untuk mendapatkan informasi yang dapat digunakan untuk mengetahui deskripsi untuk trip penangkapan (Vermard et al. 2010).

\section{HASIL DAN PEMBAHASAN}

Aktivitas kapal yang didapatkan dari data VMS diidentifikasi dengan cara mengetahui kecepatan kapal, arah gerak kapal, dan posisi kapal yang diperoleh dari data VMS. Kecepatan kapal dapat dibedakan menjadi beberapa warna untuk memudahkan dalam melakukan identifikasi aktivitas kapal tuna longline. Kecepatan dan warna serta keterangan aktivitas kapal tuna longline pada VMS disajikan dalam Tabel 3 dan pada Gambar 1 disajikan contoh tracking kapal tuna longline.

Berdasarkan hasil pengamatan data tracking VMS kapal tuna longline menunjukkan bahwa, warna hijau menunjukkan kapal bergerak dari pelabuhan ke daerah lokasi penangkapan ikan ataupun sebaliknya. Warna kuning menunjukkan kapal melakukan setting alat tangkap kemudian warna jingga menunjukkan aktivitas hauling, dan warna merah menunjukkan kapal melakukan aktivitas soak-time ataupun keadaan berhenti. Pergerakan kapal untuk warna hijau (steaming) biasanya dominan berbentuk garis lurus hal ini dikarenakan kapal sedang memiliki kecepatan yang cukup tinggi ( $>6$ knot) untuk menuju ke daerah penangkapan ikan namun hal ini biasanya terdapat pada kapal diatas 100 GT karena untuk ukuran kapal tersebut daerah penangkapan ikan berada di daerah ZEEI S. Hindia (Barat Sumatera), ZEEI S. Hindia (Selatan Jawa) dan laut lepas, dan untuk kapal berukuran 30 GT-100 GT untuk kecepatan steaming berkisar 4-5 knot dikarenakan daerah penangkapan berada di L. Bali, L. Flores, L. Sawu, SI. Makasar, TI. Bone, S. Hindia (Selatan Jawa), ZEEI S. Hindia (Selatan Jawa), L. Timor (Bag. Barat RI), ZEEI L. Timor (Bag. Barat RI), Perairan Selatan Bali (FAO 57), Perairan sebelah Selatan Nusa Tenggara Barat (FAO). Perpindahan dari keadaan kapal yang sedang dalam keadaan steaming ke keadaan dimana kapal akan melakukan operasi penangkapan ikan yang ditunjukkan oleh warna jingga dan warna kuning ditandai dengan gerakan kapal yang tidak lagi lurus dan cenderung mulai bergerak acak. Operasi penangkapan ikan kapal tuna longline memiliki pola gerak yang bervariasi namun cenderung tak beraturan. Hal ini dikarenakan pada saat melakukan setting kecepatan kapal dikurangi hingga mesin 
kapal dimatikan agar kapal dan alat tangkap hanyut terbawa arus (drifting) (Saputra et al. 2011). Pada Gambar 2 disajikan gambar titik aktivitas operasi penangkapan ikan kapal tuna longline berupa setting dan hauling.

Aktivitas kegiatan operasi penangkapan ikan oleh kapal tuna longline rata-rata dilakukan mulai pukul 05.00 dengan menurunkan alat tangkap (setting) kemudian soaking time selama 4-5 jam dan operasi penangkapan berhenti jam 19.00 sehingga dapat diestimasikan dalam satu hari kapal tuna longline dapat melakukan 4-5 kali operasi penangkapan ikan. Pada gambar 3 merupakan data yang sudah di- filter dengan waktu operasi penangkapan kapal tuna longline sehingga kecepatan kapal 2-6 knot pada waktu kapal tidak beroperasi tidak dimasukkan ke dalam titik operasi penangkapan yang diolah, karena kecepatan kapal 2-6 knot juga dapat ditemui pada waktu yang bukan merupakan waktu operasi penangkapan kapal tuna longline (pukul 19.00-04.00 WIB). Data titik untuk kecepatan kapal <2 knot (merah) menunjukkan bahwa kapal sedang dalam keadaan soaking-time atau keadaan berhenti. Berikut disajikan contoh titiktitik aktivitas kapal tuna longline dengan kecepatan $<2$ knot pada Gambar 3.

Tabel 3. Keterangan data VMS

\begin{tabular}{ccc}
\hline Kecepatan & Keterangan & Warna \\
\hline$<2$ & Soak time, idle & Merah \\
$>2-4$ & Hauling & Jingga \\
$>4-6$ & Setting & Kuning \\
$>6$ & Steaming & Hijau \\
\hline
\end{tabular}

Sumber: PUSDAL PSDKP KKP

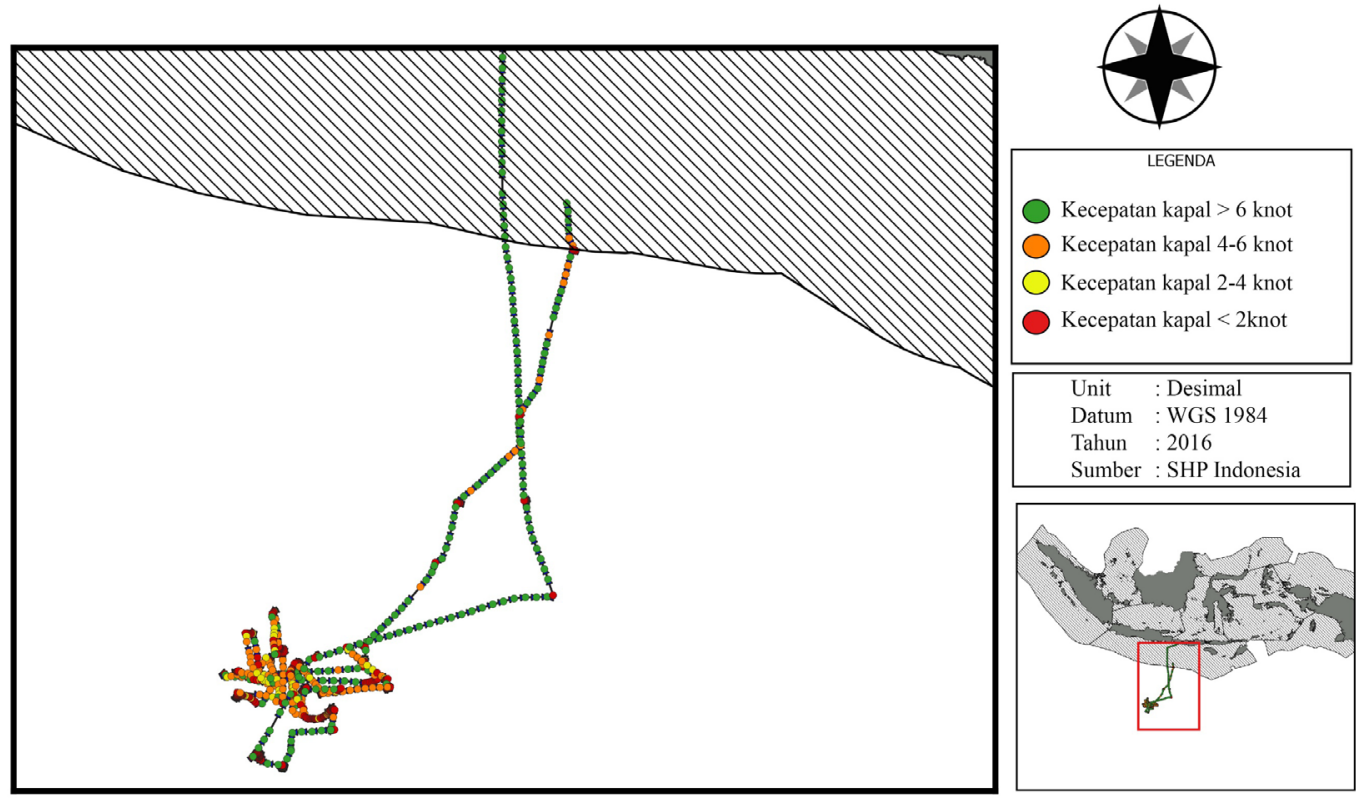

Gambar 1. Contoh tracking kapal tuna longline 


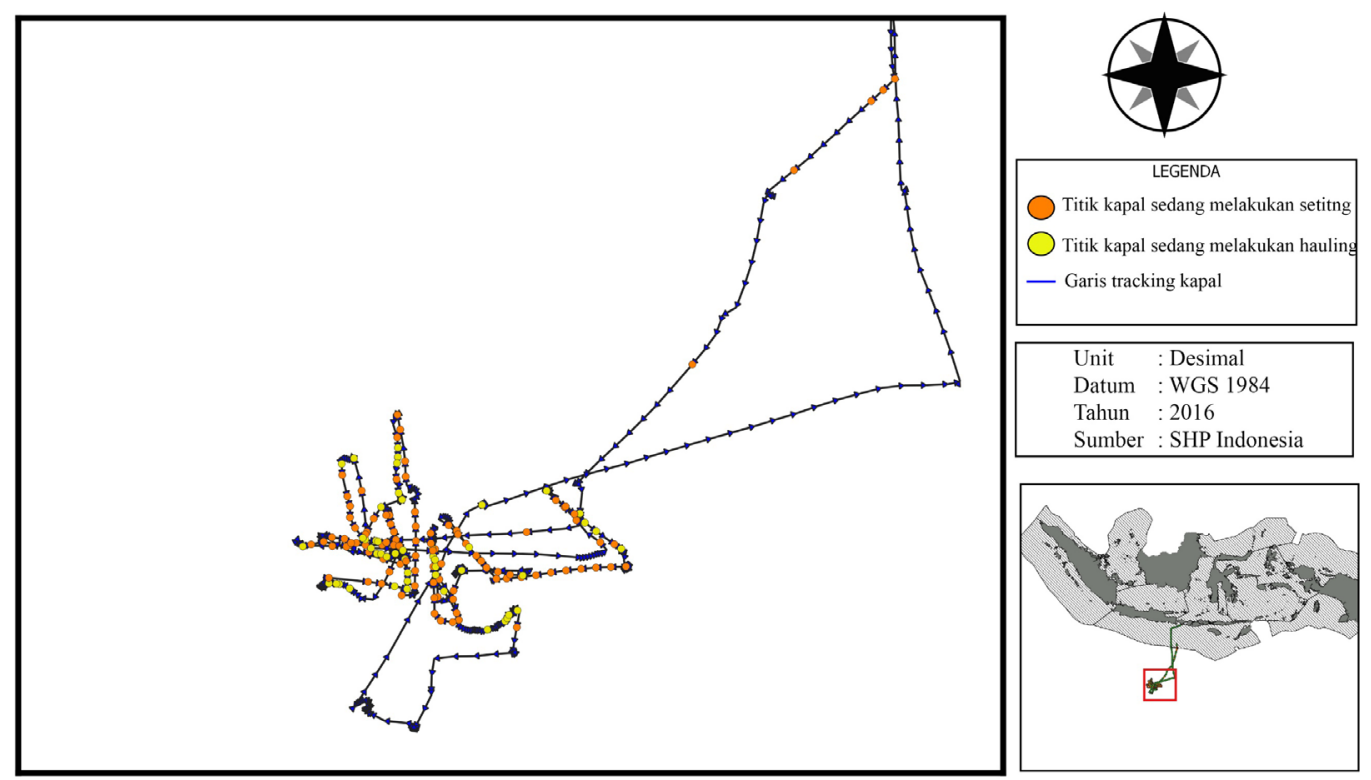

Gambar 2. Titik aktivitas kapal tuna longline

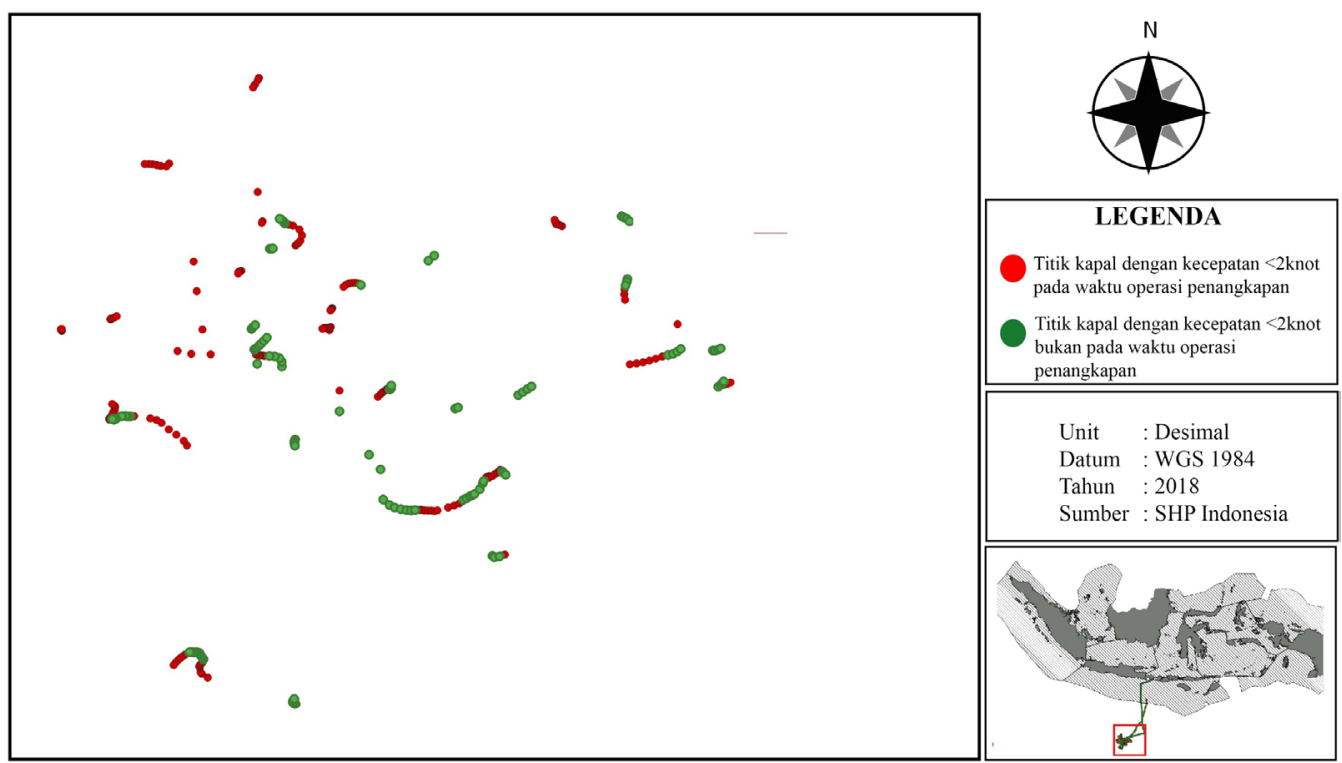

Gambar 3. Titik aktivitas kapal tuna longline dengan kecepatan $<2$ knot

Berdasarkan hasil pengamatan bahwa titik-titik kecepatan kapal tuna longline $<2$ knot memiliki setidaknya 2 pola yakni pola dimana titik-titik saling berdekatan atau berdempetan dan titiktitik yang berdiri sendiri dan posisinya cenderung acak. Titik-titik berwarna merah menunjukkan keceptan kapal tuna longline ketika $<2$ knot pada waktu operasi penangkapan sedangkan titiktitik berwarna hijau merupakan kecepatan kapal tuna longline pada waktu bukan operasi penangkapan. Tidak ada perbedaan yang signifikan pada pola kecepatan kapal tuna longline $<2$ knot, pada waktu operasi penangkapan pola dengan titik- titik yang berdekatan menunjukan bahwa kapal sedang drifting/soak-time karena kapal akan hanyut terbawa oleh arus sementara itu untuk pola dengan titik-titik yang tersebar menunjukkan bahwa kapal sedang dalam keadaan idle atau anchoring. Hal tersebut hampir sama dengan ketika tidak pada waktu operasi penangkapan ikan namun perbedaanya jika titik-titik berdempetan mengartikan bahwa kapal sedang beristirahat. Kecepatan kapal tuna longline <2 knot selain diidentifikasi di tengah laut dapat juga ditemukan dekat dengan pelabuhan yang akan disajikan pada Gambar 4. 


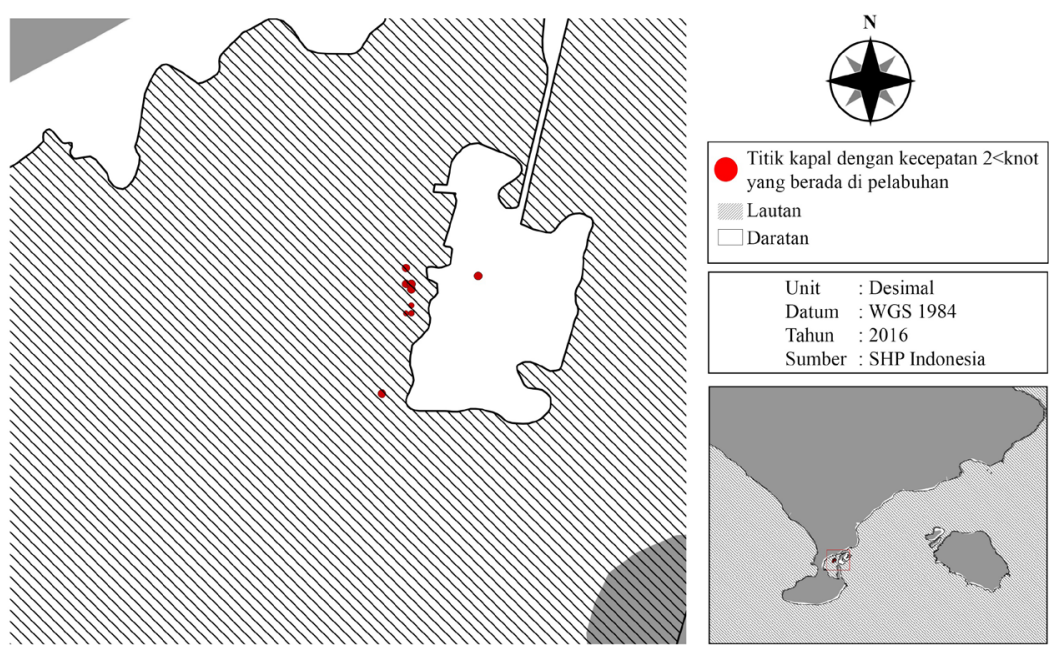

Gambar 4. Titik kecepatan kapal <2 knot yang berada di pelabuhan

Titik yang berada di luar pelabuhan menunjukkan bahwa kapal sedang berlabuh atau untuk melakukuan bongkar muat hasil tangkapan sedangkan titik yang berada di darat menujukkan kapal sedang melakukan docking kapal atau perbaikan alat transmitter. Selain kecepatan kapal yang diidentifikasi, data VMS juga dapat menentukan keberadaan posisi kapal baik sedang melakukan operasi penangkapan maupun yang sedang berlabuh di pelabuhan, arah gerak kapal dari pelabuhan menuju ke daerah penangkapan ikan ataupun sebaliknya. Hal ini sangat penting dilakukan karena analisis dapat menjadi pembanding data logbook yang ada dengan data VMS (cross-matching data). Menurut Gerritsen dan Lordan (2011) analisis terintegrasi antara data VMS dan data logbook akan memungkinkan data perikanan yang akan dianalisis pada skala spasial akan jauh lebih akurat dan juga menurut Russo (2018) menyebutkan bahwa metode kontrol yang baik untuk sebuah logbook perikanan adalah dengan menggunakan data yang dapat diandalkan dan dapat mewakili data tersebut yakni menggabungkan dua sumber informasi utama yakni data VMS dan data kedatangan kapal (baik melakukan bongkar muat atau tidak). Data cross-matching antara data VMS dan data logbook menunjukkan beberapa kejanggalan karena posisi kapal tidak berada di pelabuhan pada saat tanggal kedatangan untuk melakukan bongkar muat atau VMS dalam keadaan mati namun terdata pada tanggal saat melakukan bongkar muat. Menurut wawancara yang dilakukan dengan Kasubdit Pengendalian Operasi Penangkapan Ikan PSDKP bahwa hal tersebut merupakan salah satu modus dalam melakukan kegiatan yang mengarah kepada IUU fishing. Sebagai contoh data pendaratan kapal namun data VMS mati hal ini dapat dilakukan ketika pemilik kapal baik perorangan maupun kelompok dengan kapal yang hampir sama baik desain kapal maupun fisik kapal. Ketika akan menggunakan kapal baru tersebut pada saat pemeriksaan untuk keberangkatan kapal mereka memberikan data VMS kapal lama dan menunjukkan bahwa VMS masih tetap aktif dan berada di pelabuhan, hal ini dapat terjadi karena adanya kelalaian petugas yang tidak memeriksa secara teliti sehingga pada saat pendataan bongkar muat data VMS yang terdeteksi adalah data VMS kapal yang lama bukan kapal yang baru. Kasus kedua adalah dimana tertera tanggal bongkar muat di logbook namun kapal sedang berada di tengah laut hal ini diindikasikan terjadinya transhipment dan kelalaian petugas. Berikut disajikan pada Gambar 5 kapal yang diindikasikan melakukan transhipment dengan mematikan VMS.

Gambar 5 menunjukkan bahwa setelah meninggalkan pelabuhan kapal akan menuju ke DPI (sekitar WPP 714) namun pada lintang $8^{\circ}-10^{\circ} \mathrm{LS} 116^{\circ}-118^{\circ} \mathrm{BT}$ data VMS tidak terdeteksi (tandah panah hilang) muncul kembali $8^{\circ}-10^{\circ} \mathrm{LS} 118^{\circ}-120^{\circ}$ BT kemudian hilang dan muncul kembali di $6^{\circ}-8^{\circ}$ LS $126^{\circ}-128^{\circ} \mathrm{BT}$, sepanjang data VMS tidak terdeteksi diindikasikan bahwa kapal melakukan operasi penangkapan namun hasil tangkapannya langsung dipindahkan ke kapal lain untuk dibawa ke tempat tujuan dan ketika data VMS terdeteksi kapal sudah berada di WPP 714 . Jika terjadi hal tersebut nantinya nahkoda 
akan diminta keterangannya oleh pihak pengawas perikanan perihal data VMS tersebut tidak terdeteksi, jika diketahui melakukan pelanggaran selanjutnya hasil laporan tersebut akan diserahkan kepada pihak PSDKP untuk diberikan peringatan atau hukuman sesuai dengan undangundang dan peraturan yang berlaku.

Pengolahan data VMS yang mengidentifikasi adanya indikasi transhipment dengan cara mematikan VMS dianalisis dengan menganalisis ping kapal yang lebih dari 1 jam hal ini berdasarkan Peraturan Menteri Nomor 10/PERMENKP/2019 tentang Sistem Pemantauan Kapal Perikanan pasal 7 ayat 2 pada butir (d) disebutkan bahwa salah satu syarat SPKP adalah dapat mengirim data posisi kapal paling sedikit 1 jam sekali secara terus menerus. Berikut hasil analisis data VMS yang diindikasikan mematikan VMS untuk kegiatan transhipment yang tersaji pada Gambar 6.

Grafik pada Gambar 6 menunjukkan bahwa kapal yang mematikan VMS tertinggi terjadi pada bulan oktober 2017 dan bulan januari 2018 dengan rata-rata kapal yang diindikasikan mematikan VMS adalah kapal dengan ukuran $>100$ GT. Hal ini terjadi karena aktivitas transhipment dilakukan oleh perusahan atau nelayan karena alasan ekonomi dan efisiensi penangkapan ikan khususnya untuk kapalkapal yang berukuran besar karena dapat menghemat pengeluaran bahan bakar, dapat mengekspor langsung tuna segar ke berbagai negara sehingga keuntungan ekonomi yang didapatkan akan semakin tinggi. Namun hal ini juga akan membuat hasil tangkapan tidak didaratkan ke pelabuhan sehingga pencatatan data hasil tangkapan akan tidak akurat dan tidak terdata (unreported) yang nantinya akan berdampak terhadap pengelolaan perikanan tuna. Menurut Hartono (2007) ada beberapa alasan yang diungkapkan pemilik kapal/ pengusaha terhadap surat peringatan tentang tidak aktifnya transmitter di kapal, antara lain :

1. Menyatakan bahwa transmitter tetap aktif, tetapi tidak terpantau di Puskodal DKP Jakarta

2. Menyatakan bahwa kapal sedang melakukan docking sehingga transmitter terpaksa dimatikan

3. Transmitter menyebabkan gangguan pada peralatan lain di kapal

4. Menyatakan bahwa alat transmitter dalam keadaan rusak

5. Sedang dalam proses pengadilan

6. Kapal sedang dalam keadaan rusak

7. Perwakilan/agen sedang menunggu jawaban terhadap pemasangan transmitter

8. Sedang melakukan perubahan spesifikasi kapal dan tidak melaut

9. Surat izin atau SPI tidak diperpanjang

Data posisi kapal yang diperoleh dari VMS selain untuk mengidentifikasi pelanggaran di tengah laut data tersebut juga dapat digunakan sebagai bahan validasi posisi kapal ketika kapal mendaratkan hasil tangkapan ikan di pelabuhan. Pada Tabel 4 disajikan validasi data waktu pendaratan hasil penangkapan ikan kapal tuna longline sampel dengan data VMS (posisi kapal) yang berbasis di Benoa Bali tahun 2016-2018.

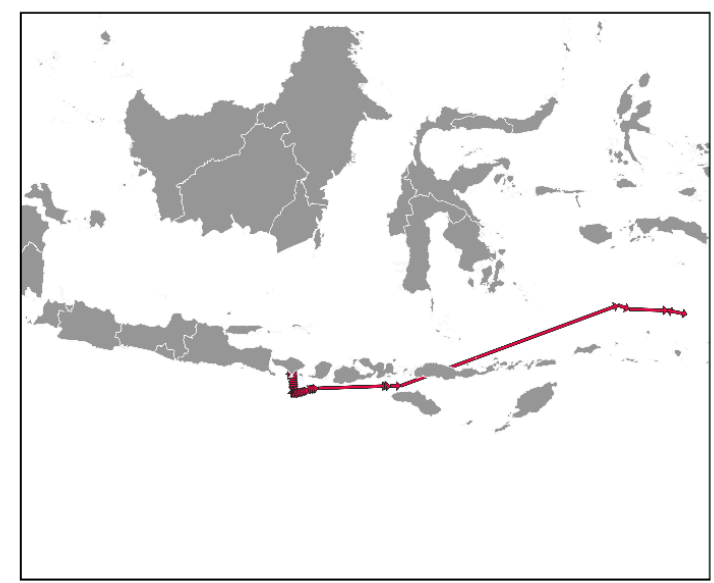

Gambar 5. Contoh tracking kapal yang diindikasikan melakukan kegiatan transhipment 


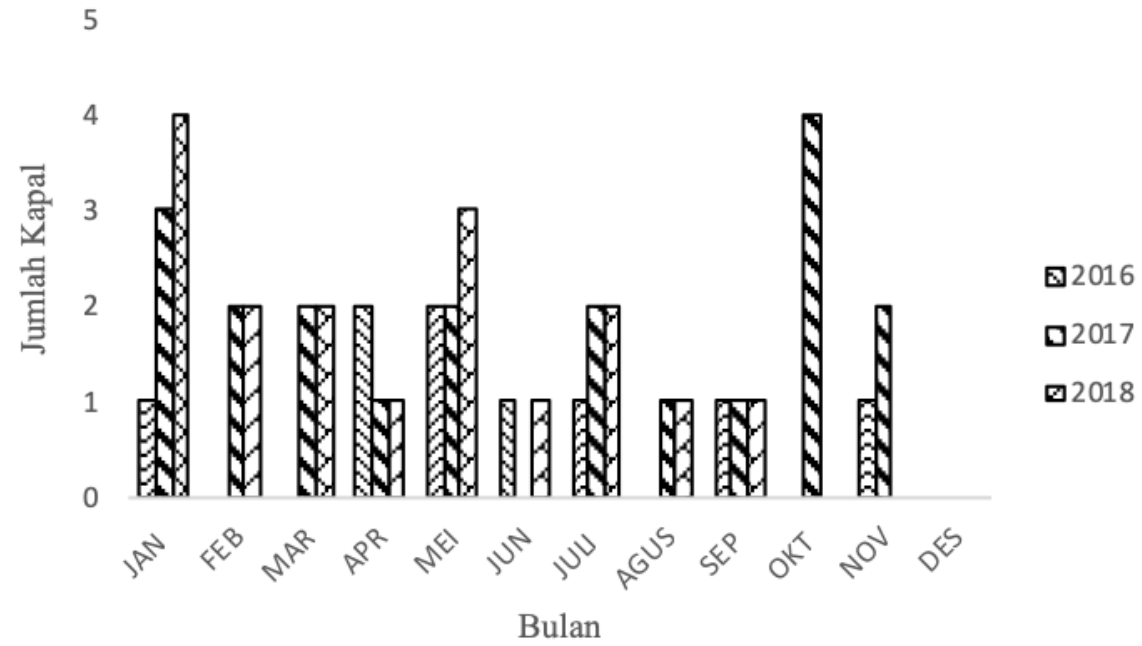

Gambar 6. Data VMS yang diindikasikan dimatikan

Tabel 4. Validasi data waktu pendaratan hasil penangkapan ikan dengan data VMS (posisi kapal) kapal tuna longline yang berbasis di Benoa Bali tahun 2016-2018

\begin{tabular}{lcccc}
\hline $\begin{array}{c}\text { No. } \\
\text { Transmitter }\end{array}$ & $\begin{array}{c}\text { Jumlah } \\
\text { pendaratan } \\
\text { hasil } \\
\text { tangkapan }\end{array}$ & $\begin{array}{c}\text { Waktu pendaratan } \\
\text { sesuai dengan data } \\
\text { VMS (Posisi kapal } \\
\text { berada di pelabuhan) }\end{array}$ & $\begin{array}{c}\text { Waktu pendaratan } \\
\text { tidak sesuai dengan } \\
\text { data VMS (Posisi } \\
\text { kapal berada di } \\
\text { pelabuhan) }\end{array}$ & $\begin{array}{c}\text { Persentase } \\
\text { (\%) }\end{array}$ \\
\hline Trx 4537518 & 3 & 3 & 0 & $100 \%$ \\
Trx 4926116 & 14 & 12 & 2 & $85 \%$ \\
Trx 4958980 & 6 & 6 & 0 & $100 \%$ \\
Trx 40517295 & 4 & 4 & 0 & $100 \%$ \\
Trx 4445802 & 12 & 8 & 4 & $67 \%$ \\
Trx 4439272 & 5 & 3 & 2 & $60 \%$ \\
$\operatorname{Trx} 4633651$ & 7 & 5 & 2 & $71 \%$ \\
$\operatorname{Trx} 4443411$ & 6 & 3 & 3 & $50 \%$ \\
$\operatorname{Trx} 4445006$ & 12 & 9 & 3 & $75 \%$ \\
$\operatorname{Trx} 4585182$ & 4 & 4 & 0 & $100 \%$ \\
$\operatorname{Trx} 4861997$ & 9 & 9 & 0 & $100 \%$ \\
$\operatorname{Trx} 4442943$ & 19 & 12 & 7 & $100 \%$ \\
$\operatorname{Trx} 81468$ & 3 & 3 & 0 & $92 \%$ \\
$\operatorname{Trx} 4934269$ & 12 & 11 & 1 & $100 \%$ \\
$\operatorname{Trx} 4964130$ & 2 & 2 & 0 & $100 \%$ \\
$\operatorname{Trx} 4949308$ & 4 & 4 & 0 & $100 \%$ \\
$\operatorname{Trx} 4926124$ & 16 & 16 & 0 & $100 \%$ \\
$\operatorname{Trx} 4941366$ & 10 & 10 & 0 &
\end{tabular}


Berikut disajikan pada Gambar 7 terkait data cross-matching antara data logbook dengan data VMS. Jumlah ketidaksesuain data logbook dan data VMS mengalami penurunan yang cukup drastis dari tahun 2016 sampai tahun 2018 dimana pada tahun 2016 tercatat ada 21 data yang tidak sesuai antara data logbook dan data VMS, pada tahun 2017 sebanyak 3 data dan pada tahun 20181 data. Sedangkan untuk data yang sesuai antara data logbook dan VMS dari tahun 2016-2017 mengalami peningkatan yang signifikan dan cenderung stagnan sampai tahun 2018 dengan tingkat kesesuaian data pada tahun 2016 sebesar $53 \%$, tahun 2017 sebesar 94\%, dan tahun 2018 sebesar 98\%. Hal ini dikarenakan pemerintah baik dari pusat maupun daerah dan pihak stakeholderyang terkait bersamasama mengupayakan pembenahan data logbook ini sehingga terciptanya data yang dapat digunakan sebagai salah satu sumber untuk melakukan pengelolaan perikanan yang lebih baik dan akurat.

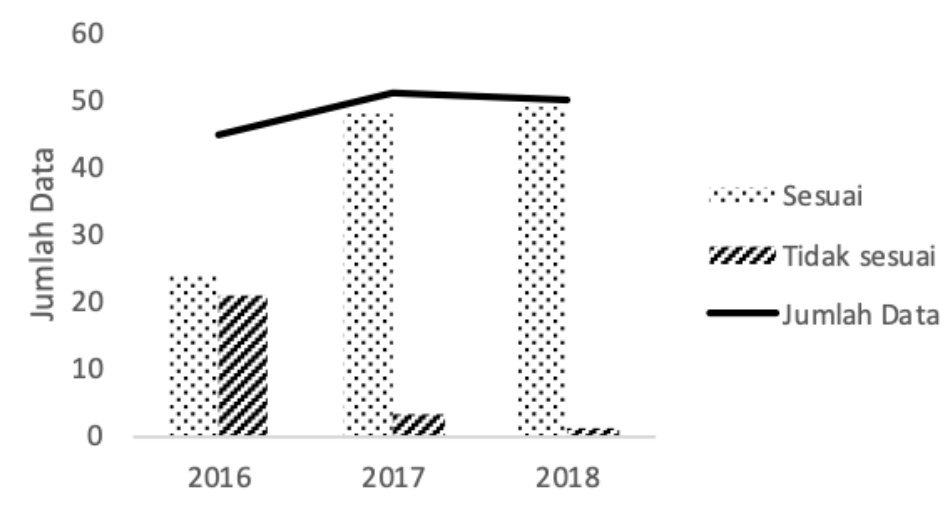

Gambar 7. Cross-Matching data logbook dan data VMS

\section{KESIMPULAN DAN SARAN}

\section{Kesimpulan}

1. Aktivitas kapal tuna longline berdasarkan kecepatan kapal yang didapatkan dari data VMS terdiri dari 4 aktivitas yakni ketika kapal $<2$ knot menunjukkan bahwa kapal sedang dalam keadaan soaking time atau berhenti ( 0 knot), kapal dengan kecepatan 2-4 knot menunjukkan kapal sedang melakukan hauling, kapal dengan kecepatan 4-6 knot menunjukkan kapal sedang melakukan setting, dan kapal dengan kecepatan $>6$ knot menunjukkan bahwa kapal melakukan steaming.

2. Jumlah ketidaksesuain data logbook dan data VMS di Benoa mengalami penurunan yang cukup drastis dari tahun 2016 sampai tahun 2018 dimana pada tahun 2016 tercatat ada 21 data yang tidak sesuai antara data logbook dan data VMS, pada tahun 2017 sebanyak 3 data dan pada tahun 20181 data. Sedangkan untuk data yang sesuai antara data logbook dan
VMS dari tahun 2016-2017 mengalami peningkatan yang signifikan dan cenderung stagnan sampai tahun 2018 dengan tingkat kesesuaian data pada tahun 2016 sebesar 53\%, tahun 2017 sebesar 94\%, dan tahun 2018 sebesar $98 \%$.

\section{Saran}

1. Perlu adanya pembaharuan sistem VMS dengan menggabungkan dengan data-data lainnya seperti data e-logbook dalam satu kesatuan sistem

2. Perlu adanya penelitian lanjutan mengenai fishing activity untuk jenis kapal perikanan lain

\section{DAFTAR PUSTAKA}

[FAO]. 2007. APFIC Regional Consultative Workshop Managing Fishing Capacity and IUU fishing in the Asian region Phuket, Thailand 13-15 June 2007.

[KKP] Kementerian Kelautan Perikanan. 2007. Peraturan Menteri Kelautan dan Perikanan Nomor Per.05/ 
MEN/2007 tentang Penyelenggaraan Sistem Pemantauan Kapal Perikanan. Jakarta.

[KKP] Kementerian Kelautan Perikanan. 2014. Peraturan Menteri Kelautan dan Perikanan Nomor 57/PermenKP/2014 tentang Perubahan Kedua atas Peraturan Menteri Kelautan dan Perikanan Nomor PER.30/ MEN/2012 tentang Usaha Perikanan Tangkap di Wilayah Pengelolaan Perikanan Negara Republik Indonesia. Jakarta.

[KKP] Kementerian Kelautan Perikanan. 2015. Peraturan Menteri Kelautan dan Perikanan Nomor 42/Permen$\mathrm{KP} / 2015$ tentang Sistem Pemantauan Kapal Perikanan. Jakarta.

[KKP] Kementerian Kelautan Perikanan 2019. Peraturan Menteri Kelautan dan Perikanan Nomor 10/PermenKP/2019 tentang Sistem Pemantauan Kapal Perikanan. Jakarta.

Gay LR, Diehl PL. 1992. Research Methods for Business and. Management. MacMillan Publishing Company New York.

Gerritsen H, Lordan C. 2011. Integrating Vessel Monitoring Systems (VMS) Data with Daily Catch Data from Logbooks to Explore the Spatial Distribution of Catch and Effort at High Resolution. ICES J. Mar. Sci. 68(1): 245-252.

Hartono BD. 2007. Analisis Model Vessel Monitoring System (VMS) dalam
Pengawasan Kapal Penangkap Ikan di Indonesia [Disertasi]. Bogor: Institut Pertanian Bogor.

Jatmiko I, Setyadji B, Novianto D. 2016. Produksi Perikanan Tuna Hasil Tangkapan Rawai Tuna yang Berbasis di Pelabuhan Benoa, Bali. J. Peneliti. Perikanan. Indonesia. 22(1): 25 .

Natsir M, Atmaja SB. 2013. Aktivitas Penangkapan Individu Kapal Purse Seine di Laut Maluku: Sistem Pemantauan Kapal (VMS) dan Observer Fishing Activity of Individual Purse Seiners in Molucca Sea: Vessel Monitoring System (VMS) and Observers. J. Lit. Perikan. Ind. 19(1): 17-24.

Russo T, Morello EB, Parisi A, Scarcella G, Angelini S, Labanchi L, Martinelli M, D'Andrea L, Santojanni A, Arneri E, Cataudella S. 2018. A Model Combining Landings and VMS Data to Estimate Landings by Fishing Ground and Harbor. Fish. Res. 199: 218-230.

Saputra WS, Solichin A, Wijayanto D, Kurohman F. 2011. Produktivitas dan Kelayakan Usaha Tuna Longliner di Kabupaten Cilacap Jawa Tengah. J. Saintek Perikan. 6(2): 84-91.

Vermard Y. 2010. Archimer Identifying Fishing Trip Behaviour and Estimating Fishing Effort from VMS. Ecol. Modell. 221(15): 1757-1769. 